\title{
電力系統の過渡安定度解析のための故障計算手法
}

\author{
正員田 中和 幸 (九州工大・電力中研) \\ 正員浅田実 (電力中研)
}

\section{Fault Calculation Method for Transient Stability Study of Electric Power System}

Kazuyuki Tanaka, Member (Kyushu Institute of Technology, CRIEPI), Minoru Asada, Member (CRIEPI)

As concerns faults analysis in transient stability study, balanced fault condition such as 3-lines grounded has been adapted for long time in Japan. So transient stability software calculating only balanced fault has been utilized. However, with the advance of system protective control technologies such as multi-phase reclosing system for faulted transmission line, the stability software are needed which enable to calculate unbalanced faults including multiple faults conditions.

This report presents the newly developed calculation method of system faults which enable to calculate unbalanced single or multiple faults with the addition of balanced faults, and the validity of presented method was shown through the comparison to the results of test simulator. Moreover the report describes how transient stability limits are difierent for various faults conditions.

キーワード：過渡安定度解析, 故障計算, 対称座標法

\section{1.まえがき}

我が国では, 長距離・大電力の輸送を担う基幹電力 系統のほとんどが架空送電線で構成されている。これ らの送電線は地理的に大きな広がりをもち，また架間 的に無防備な状態にさらされているため, 雷を主とす る外部からの影響（系統外乱）を受ける危険が避けら れない。この系統外乱は, 一般に送電線への地絡故障 として多く現れ，その対処いかんは供給支障と密接な 関係がある。従って, 電力系統の拡充計画や運用計画 にあたっては，ある一定の厳しさまでの系統外乱を受 けても供給支障を生じないような設備構成や運用の指 針が設定されている。指針の対象となる系統外乱の基 準は，一般に想定故障条件と呼ばれている。

この指針は設備増強や潮流調整などの対策として具 体化され，その際の技術的要因に潮流過負荷や定態安 定度, 過度安定度, 電圧安定度などがあることはよく 知られている。これらのなかで，広域な連系により大 規模系統を構成している我が国においては過渡安定度
が最大のネックの一つとなっている。

従来, 過渡安定度解析に扝省定故障条件の多く は送電線の三相地絡故障/三相主保護遮断（3LG/ 3LO）である(1)。しかし表 1 に示すように，我が国の 超高圧基幹系統における最近の故障実績は一相地絡故 障 (1 LG) 怔総故障数の大半を占め, 一方で 2 回線 にまたがる同時故㖏の発生頻度が無視しえない状況に あるなど，故障実態と想定故障レベルとのかい離が見 受けられる。

また, 最近の超高圧基幹送電線の多くは, 地域的に 方式の差哄はあるものの, 故障送電線の高速復旧を目 的とした単相ないしは 2 回線にまたがる多相再閉路方 式の採用により，供給信頼度の向上が図られている。 こうしたことから，より効率的な系統計画・運用の実 現のため，あるいはまた関連業務における検討精度の いっそうの向上のため, 過渡安定度解析で想定する故 障条件について従来の $3 \mathrm{LG} / 3 \mathrm{LO}$ といった平衡故障 に加えて, 実態をより反映した各種の不平衡故障条件 の設定が必要となっている。 
安定度解析への適用を目的とした故障計算手法とし ては最近，相座標法(2) の上うな新しい手法も提案さ れてはいるが，教育の場や電気事業などの実務では長 年, 対称座標法 ${ }^{(4)}$ が広く用いられており, 従って本諭 文でも対称座標法に基づく故障計算を対象とする。

従来, 故障計算は電力系統保護の分野において, 地 絡・短絡・断線の単純故障のほか, 2 異地点での同時地 絡（多重地絡故障）や断線を伴う地絡などの多重故障 について，ノードインピーダンス行列（以下， $Z$ 行 列と呼ぶ）を用いた計算手法が開発されている(5)(6)。 しかし, 大規模電力系統の過渡安定度解析への適用を 前提とし, 送電線の多相再閉路シミュレーションなど に必要な 2 異地点での同時断線計算を含む多種多様な 故障計算手法が開発・塞用化された例はこれまで見当 たらない。なお, 安定度解析では, この断線計算の多 くが故障送電線の開放遮断を目的として使用される。

この断線計算が多く用いられてこなかった理由とし て, 特に不平衡断線故障に関する従来の計算方法が, 今日定着しているノードアドミタンス行列 (以下， $Y$ 行列と呼ぶ) ベースでの過渡安定度解析には不向きな ことが指摘できる。

従来の不平衡断線計算では, いったん各対称分回路 の断線点を開放する必要がある。断線点の開放は断線 点ノードの追加を意味するが,これを $Y$ 行列ベース で行う場合, 次数の増加に伴いノードの順序付けや三 角化行列への分解など多くの再計算を必要とする。そ の結果, 全体のプログラム構成や計算効率の大きな悪 化をまねくことになる（ちなるに，計算のベースがZ 行列であれば次数の変更は容易。しかし大規模系統へ の適用は困難)。特に過渡安定度解析では, 計算の時 間軸に沿って故障様相が様々に移り変わり得る,すな

表 $1187 \mathrm{kV}$ 以上の 2 回線送電線の雷事故 実績(3) (1980年4月～1985年3月，電力 10 社）

Table 1. The record of lightning faults on double circuits over $187 \mathrm{kV}$.

\begin{tabular}{|c|c|c|c|}
\hline \multicolumn{2}{|c|}{ 故障㥞相 } & 雷 & I 散 \\
\hline 相数 & 地 絡 数 & 件 数 & 割合 (\%) \\
\hline $1 \phi$ & $\begin{array}{l}1 \mathrm{LG} \\
2 \mathrm{LG}\end{array}$ & $\begin{array}{r}481 \\
3\end{array}$ & $\begin{array}{r}72.8 \\
5.3\end{array}$ \\
\hline $2 \phi$ & $\begin{array}{l}2 \mathrm{LG} \\
3 \mathrm{LG} \\
4 \mathrm{LG}\end{array}$ & (8) $\begin{array}{lll}6 & 6 \\
& 2 & 1 \\
& 1 & 4\end{array}$ & $\begin{array}{r}10.0 \\
3.2 \\
2.1\end{array}$ \\
\hline $3 \phi$ & $\begin{array}{l}3 \mathrm{~L} G \\
4 \mathrm{~L} G \\
5 \mathrm{~L} G \\
6 \mathrm{~L}\end{array}$ & (1) $\begin{array}{r}20 \\
\\
\\
\\
\\
\\
\end{array}$ & $\begin{array}{l}3.0 \\
1.2 \\
1.1 \\
1.4\end{array}$ \\
\hline 合 & 邻 & 661 & 100.0 \\
\hline
\end{tabular}

(注)（）内缐にまたがる事故性数
わち $Y$ 行列の再計算が頻繁に生じることが前提とな ることを考えれば， $Y$ 行列ベースでの計算の困難さ が推察される。

本論文ては, 大規模電力系統の過渡安定度解析への 適用を前提として, 従来手法の延長ではその適用が困 難な断線計算を含む故障計算の新しい定式化と，それ に基づく効率的な計算法を提案する。また，モデル実 験による提案手法の精度検証, 更に各種の事故様相と 過渡安定度限界との関係について考察する。

次章では，まず安定度解析における故障計算の概要 と, 提案する故障計算手法について述べる。

\section{2. 故障計算手法}

本章では, 対称座標法に基づく単純・多重故障計算 の新しい計算手法を提案する。

対象とする故障は, 表 2 に示す 48 の故障種類であ る。以下では,この 48 種類の故障の計算が, わずか 9 種類の統一された計算式の下で効率的に行い得るこ とを示す。

提案する故障計算は過渡安定度解析中の系統計算と 密接なかかわりがあるため,まず次節で過渡時の系統 計算について触れる。

$\langle 2 \cdot 1\rangle$ 過渡時系統計算と故障計算 過渡安定度 解析を数值積分により行う場合，積分刻み時間の断面

表 2 取扱う故障条件の範囲

Table 2. Classification of system faults.

\begin{tabular}{|c|c|c|}
\hline & 取り报う故隐条件 & $\begin{array}{l}\text { 提悹手法に基づ } \\
\text { く故障の分類 }\end{array}$ \\
\hline \multirow{3}{*}{$\begin{array}{l}\text { 単 } \\
\text { 純 } \\
\text { 警 } \\
\text { 变 }\end{array}$} & $1 \mathrm{LG}, 1 \mathrm{LO}, 1 \mathrm{LA}$ & $1 \mathrm{~L}$ \\
\hline & $2 \mathrm{LG}, 2 \mathrm{LO}, 2 \mathrm{LA}$ & $2 \mathrm{~L}$ \\
\hline & $3 \mathrm{LG}, 3 \mathrm{LO}, 3 \mathrm{LA}$ & $3 \mathrm{~L}$ \\
\hline \multirow{2}{*}{ 多 } & 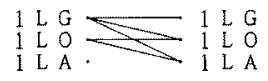 & $1 \mathrm{~L} \longrightarrow 1 \mathrm{~L}$ \\
\hline & $\begin{array}{l}1 \mathrm{LG} \\
1 \mathrm{LO} \\
1 \mathrm{LA}\end{array}$ & $1 \mathrm{~L} \longrightarrow 2 \mathrm{~L}$ \\
\hline 重 & 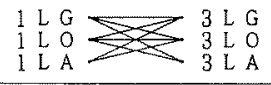 & $1 \mathrm{~L} \longrightarrow 3 \mathrm{~L}$ \\
\hline 故 & $\begin{array}{l}2 \mathrm{LG} \\
2 \mathrm{LG} \\
2 \mathrm{~L} \rightleftharpoons \mathrm{L} \\
2 \mathrm{LA}= \\
2 \mathrm{LA}\end{array}$ & $2 \mathrm{~L} \longrightarrow 2 \mathrm{~L}$ \\
\hline \multirow[t]{2}{*}{ 障 } & $\begin{array}{l}2 \mathrm{LG} \\
2 \mathrm{LO} \\
2 \mathrm{LA}\end{array} 2 \sum \begin{array}{l}3 \mathrm{LG} \\
3 \mathrm{~L} \\
3 \mathrm{LA}\end{array}$ & $2 \mathrm{~L} \longrightarrow 3 \mathrm{~L}$ \\
\hline & $\begin{array}{l}3 \mathrm{LG}=3 \mathrm{LG} \\
3 \mathrm{~L} \mathrm{O}=3 \mathrm{~L} \mathrm{O} \\
3 \mathrm{LA}=3 \mathrm{~L} \mathrm{~A}\end{array}$ & $3 \mathrm{~L} \longrightarrow 3 \mathrm{~L}$ \\
\hline 部 & 48 䨪 類 & 種 類 \\
\hline
\end{tabular}

(注) G：地船、O：繶路關放、A：SrC 短絡

T. IEE Japan, Vol. 112-B, No. 5, '92 
ごとに系統のノード電王やブランチ電流を計算するこ とが必要となる。本論文では，この計算を過渡時系統 計算と呼ぶ。通常，過渡時系統計算は負荷特性や後述 の系統故障計算を含み，また発電機の動摇方程式から 導かれるノードへの注入電流を計算条件とする理由な どから，一般の潮流計算と異なり次式のような $Y$ 行 列べースでの計算となる。

$$
i_{1}=\dot{Y}^{(1)} \dot{V}_{1}
$$

ここに, 添字 1 : 正相分, $\dot{Y}^{(1)}$ : 正相 $Y$ 行列,

$i_{1}:$ ノドの注入電流べクトル, $\dot{V}_{1}:$ ノド

電圧ベクトル（いずれの変数も複素数）

(1)式で， $\dot{Y}^{(1)}$ と $i_{1}$ を既知としてノード電圧 $\dot{V}_{1}$ を計 算することがその時間断面に讼ける系統計算である。 えの各要素は，例えば系統負荷がすべて定インピーダ ンス特性（消費電力が電圧の 2 乗に比例）モデルでか つ故障がない場合は，ベクトル $i_{1}$ の発電機ノードに 対応する位置だけに注入電流が設定され，その他はす べてゼロ値という特徵を有する。もし，過渡安定度の 数值積分法として四次のルンゲクッタ法を用いるなら ば，積分刻み時間だけ計算を進めるために(1)式の計 算が最小限 4 回は必要となる。

な怙，(1)式による $\dot{V}_{1}$ の求解には，今日ではもつ ぱら $Y$ 行列の疎性に着目した効率的方法（三角化行 列への分解手順による方法）が用いられる(7)。

さて, 次節以下の故障計算は (1) 式の過渡時系統計 算に含まれるが，故障計算には大別して次の二つの方 法が考えられる。

(i) 故障樣相に応じて $Y$ 行列要素を変更する方 法（故障点への故障等価抵抗の㨉入）

（ii）故障様相に応じた故障電流值を計算し, 注入 電流として計算する方法（故障点への故障等価 電流の注入)

一般に，不平衡故障を含む故障計算方法として両者 を比較すると，故障条件が単純故障であってかつ正相 分のみに関する系統諸量が得られれば十分な場合は前 者が扱いやすい。一方, 多重故障も考慮する場合, あ るいは同時に系統各部に扔ける各相電圧・電流諸量も 必要とする場合将後者が優れている。特に不平衡の多 重故障計算に関しては, 一般の大規模電力系統モデル の場合, 前者の方法では挿入する等価抵抗に相互分が 生じここによる計算は容易ではない(8)。

従って, 以下では (ii) を前提とした故障計算手法に ついて述べる。この場合, 故障計算は (1) 式をべース として, 正相分については

$$
i_{1}+\Delta i^{(1)}=\dot{Y}^{(1)} \dot{V}_{1}
$$

逆相分，零相分についてはそれぞれ

$$
\begin{aligned}
& \Delta i^{(2)}=\dot{Y}^{(2)} \dot{V}_{2} \\
& \Delta i^{(0)}=\dot{Y}^{(0)} \dot{V}_{0}
\end{aligned}
$$

により各対称分のノード電圧 $\dot{V}$ を求めることになる。 $\Delta i$ は系統故障を模擬するための故障点ノードへの注 入電流ベクトルである。従って，各々の故障条件に応 じた $\Delta i$ を求めることが故障計算の目的となる。

$\langle 2 \cdot 2\rangle$ 単純故障計算 単純故障計算の基本計算 式を表 3 に示す。な挍，対称座標法の基本論理，ある いは故障位相が非基準相の場合の計算などについて は，例えば文献 (9)などの関係著書を参照されたい。 以下では特に断らない限り, 故障位置はノード端, 故 障位相は基準相（1 線故障の場合は $a$ 相， 2 線故障の 場合は $b c$ 相) を指すものとする。また，記述にあた って複素記号は省略する。

表 3 の地絡故障および直列コンデンサ (SrC) 短絡 故障の基本式は，既に広く用いらている方法である。 しかし，断線計算は本論文で提案するものであり，以 下に定式化の手順を述べる。まず，従来の断線計算の 基本式仗次のとおりである。

$$
\left.\begin{array}{l}
V_{k}{ }^{(0)}=-\left[Z_{s s}{ }^{(0)}+Z_{t t}{ }^{(0)}\right] I_{k}{ }^{(0)} \\
V_{k}{ }^{(1)}=-\left[Z_{s s}{ }^{(1)}+Z_{t t}{ }^{(1)}\right] I_{k}{ }^{(1)}+E_{k} \\
V_{k}{ }^{(2)}=-\left[Z_{s s}{ }^{(2)}+Z_{t t}{ }^{(2)}\right] I_{k}{ }^{(2)}
\end{array}\right\}
$$

ここに， $t:$ 断線による回路変更に伴い新し

く追加されたノード, $E_{k}$ : 斨線点を開いた 状態でのノード $s$ と $t$ 間の電位差, $Z$ : 断線状

態の各対称分回路の $Z$ 行列要素[図 1(a)]

このように，従来の方法では計算にあたっていったん 回路変更計算を行う必要がある。また，求めるべき変 数も電流值 $I_{k}$ として定式化されている。

提案する方法では，まず( 3 )式を次のように亩換え る。

$$
\begin{aligned}
& I_{k}{ }^{(0)}=-V_{k}{ }^{(0)} /\left(Z_{s s}{ }^{(0)}+Z_{t t}{ }^{(0)}\right) \\
& I_{k}{ }^{(1)}=-V_{k}{ }^{(1)} /\left(Z_{s s}{ }^{(1)}+Z_{t t}{ }^{(1)}\right) \\
& +E_{k} /\left(Z_{s s}{ }^{(1)}+Z_{t t}{ }^{(1)}\right) \\
& \left.I_{k}{ }^{(2)}=-V_{k}{ }^{(2)} /\left(Z_{s s}{ }^{(2)}+Z_{t t}{ }^{(2)}\right)\right)
\end{aligned}
$$

上の式で，右辺の $V_{k}$ にかかる係数は，奏は各対称分 回路の断線点から直列に回路を親いたときのアドミタ ンスに等しい。すなわち,

$$
Y_{k k}{ }^{(n)}=1 /\left(Z_{s s}{ }^{(n)}+Z_{t t}{ }^{(n)}\right) \quad(n=0,1,2,)
$$

また，正相分方程式の右辺第 2 項は，断線前に当該点 を流れていた電流 $C_{k}$ に等しい。すなわち，

$$
C_{k}=E_{k} /\left(Z_{s s}^{(1)}+Z_{t t}^{(1)}\right)
$$


表 3 単純故障計算式

Table 3. Fundamental equation of single contingency.

\begin{tabular}{|c|c|c|c|c|c|}
\hline$x_{3}$ & (a) 地絡 故 喓 & (b) $\mathrm{SrC}$ 㛒故障 & (c) 䉼 線 故 & \multirow{6}{*}{$\Rightarrow$} & (d) 稓一的 数 现 \\
\hline 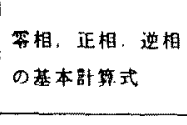 & 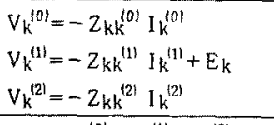 & $\begin{array}{l}V_{k}^{(0)}=-R_{s r}^{(0)} I_{k}^{(0)} \\
V_{k}^{(1)}=-R_{s r}^{(1)} I_{k}^{(1)}+E_{k} \\
V_{k}^{(2)}=-R_{s r}^{(2)} l_{k}^{(2)}\end{array}$ & $\begin{array}{l}I_{k}^{(01}=-Y_{k} k^{(01} V_{k}^{(0)} \\
I_{k}^{(1)}=-Y_{k k}^{(1)} V_{k}^{(11)}+C_{k} \\
I_{k}^{(2)}=-Y_{k k} k^{(2)} V_{k}^{(2)}\end{array}$ & & $\begin{array}{l}U_{k}^{(01)}=-X_{k k}^{(0)} W_{k}^{(0)} \\
U_{k}^{(1)}=-x_{k} k^{111} W_{k}^{(1)}+S_{k} \\
U_{k}^{(2)}=-X_{k} k^{i 21} W_{k}^{(2)}\end{array}$ \\
\hline 故陎式 & $\begin{array}{l}1 L G\left(\begin{array}{l}V_{k}^{(0)}+V_{k}^{(1)}+V_{k}^{(2)}=0 \\
I_{k}^{(0)}=I_{k}^{(1)}=I_{k}^{(2)}\end{array}\right. \\
2 L G\left(\begin{array}{l}V_{k}^{(0)}=V_{k}^{(1)}=V_{k}^{(2)} \\
l_{k}^{(0)}+I_{k}^{(1)}+I_{k}^{(2)}=0\end{array}\right. \\
3 L G V_{k}^{(0)}=V_{k}^{(1)}=V_{k}^{(2)}=0\end{array}$ & $\begin{array}{l}I L A\left(\begin{array}{l}V_{k}^{(0)}+V_{k}^{(11)}+V_{k}^{(2)}=0 \\
I_{k}^{(0)}=I_{k}^{(1)}=I_{k}^{(2)}\end{array}\right. \\
2 L A\left(\begin{array}{l}V_{k}^{(0)}=V_{k}^{(1)}=V_{k}^{(2)} \\
I_{k}^{(0)}+I_{k}^{(1)}+I_{k}^{(2)}=0\end{array}\right. \\
3 L A \quad V_{k}^{(0)}=V_{k}^{(1)}=V_{k}^{(2)}=0\end{array}$ & 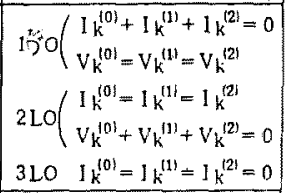 & & 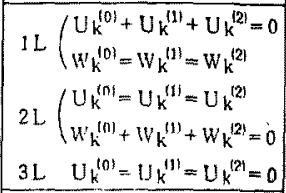 \\
\hline 知 要 效 & $I_{k}{ }^{101}, I_{k}{ }^{(1)}, I_{k}{ }^{21}$ & $I_{k}^{(0)}, I_{k}^{(1)}, I_{k}^{(2)}$ & $v_{k}^{(10)}, v_{k}^{(1)}, v_{k}^{(2)}$ & & $w_{k}^{101}, w_{k}{ }^{(1)} \cdot w_{k}^{(2)}$ \\
\hline 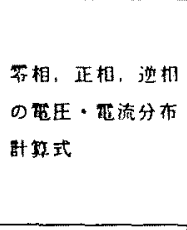 & 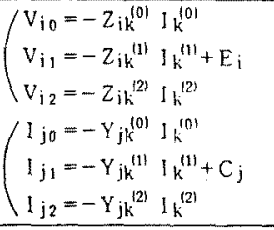 & 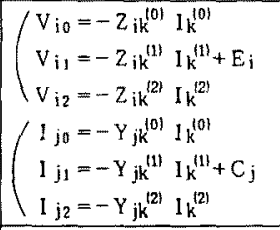 & 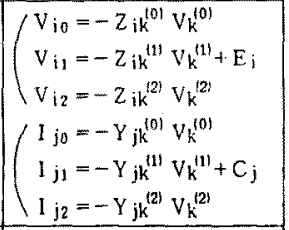 & & 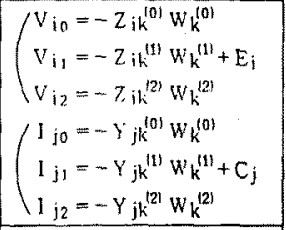 \\
\hline $\begin{array}{c}\text { 各変数の味 } \\
(n=0,1,2)\end{array}$ & 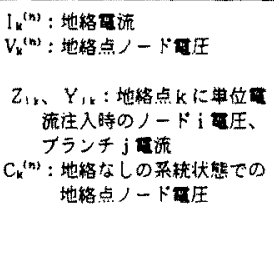 & 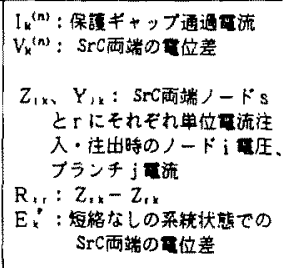 & 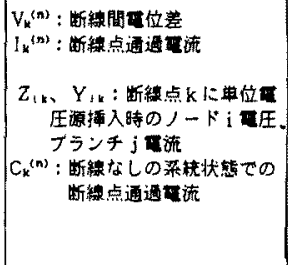 & & \\
\hline
\end{tabular}

よって, (4) (6)式より次式を得る。

$$
\left.\begin{array}{l}
I_{k}{ }^{(0)}=-Y_{k k}{ }^{(0)} V_{k}{ }^{(0)} \\
I_{k}{ }^{(1)}=-Y_{k k}{ }^{(1)} V_{k}{ }^{(1)}+C_{k} \\
I_{k}{ }^{(2)}=-Y_{k k}{ }^{(2)} V_{k}{ }^{(2)}
\end{array}\right\}
$$

この式が提案する断線計算式である。本方法では， 従来の方法と異なり断線点 $k$ を開放する必要がない。 すなわち，(7)式中のアドミタンス值 $Y_{k k}$ 洨, 図 1(b)に示すように断線点に単位電圧源を㨂入したと きの $k$ 点通過電流として得ることができる。このブ ランチ插入電圧源の計算は, 上く知られているよう に, 当該ブランチの両端ノードへの等価注入電流 （Nortonの電流源）計算として容易に行うことがで き, $Y$ 行列要素の再計算は不要である。

更に，（7)式は表 3 中のほかの計算式と全く同形て あるため，次のような利点がある。すなわち，単純故 障の故障稼相として考えられる表 2 の夕イプそれぞ れの末知変数 $\Delta i$ を求めるにあたって，個別に九つの 計算式を用意する必要がない。本方法では，表 $3(\mathrm{~d})$ に示す統一的表現形式について，以下の上うに $1 L, 2$ $L$ 极よび $3 L$ 故障の 3 タイプのみに関する求解式を 用意しておきさえすればよい。

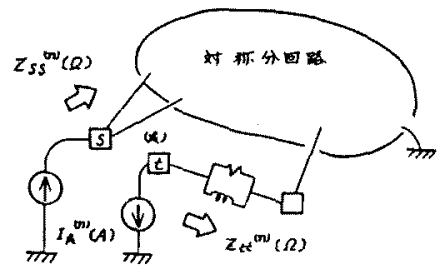

(a)遈来们方法

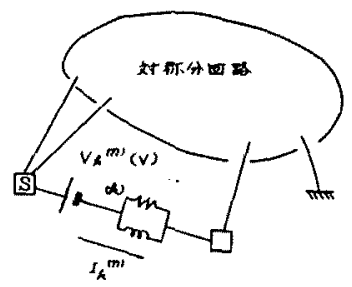

(b)提案する方法

図 1 断線故障計算方法

Fig. 1. Calculating technique of line open.

末知変数べクトル $\Delta i$ 注, 故障ノードの未知変数 $W_{k}$ 除いて他はすべてゼロである。この $W_{k}$ は，表 3(d)の統一的表現式に対して 
表 4 単純故障計算の係数 $C$ (表 $3(d)$ に対応)

Table 4. Coefficients used for single fault calculation.

\begin{tabular}{|c|c|c|c|}
\hline 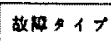 & $1 \mathrm{~L}$ & $2 \mathrm{~L}$ & $3 \mathrm{~L}$ \\
\hline & 1 & $x_{k k}^{(0)}+x_{k k}^{(2)}$ & 1 \\
\hline$c_{1}$ & $\overline{X_{k k}^{(0)}+X_{k k}^{(1)}+X_{k k}^{(2)}}$ & $x_{k k}^{(0)} x_{k k}^{(1)}+x_{k k}^{(1)} x_{k k}^{(2)}+x_{k k}^{(2)} x_{k k}^{(0)}$ & $\mathrm{x}_{\mathrm{kk}}^{\mathrm{Ul} / \mathrm{k}}$ \\
\hline $\mathrm{C}_{0}$ & 1 & $-\frac{x_{k k}^{(2)}}{x_{k k}^{(0)}+x_{k k}^{(2)}}$ & 0 \\
\hline$C_{2}$ & 1 & $-\frac{x_{k k}^{101}}{x_{k k}^{(0)}+x_{k k}^{(2)}}$ & 0 \\
\hline
\end{tabular}

表 5 多重故障計算式

Table 5. Fundamental equation of multiple faults.

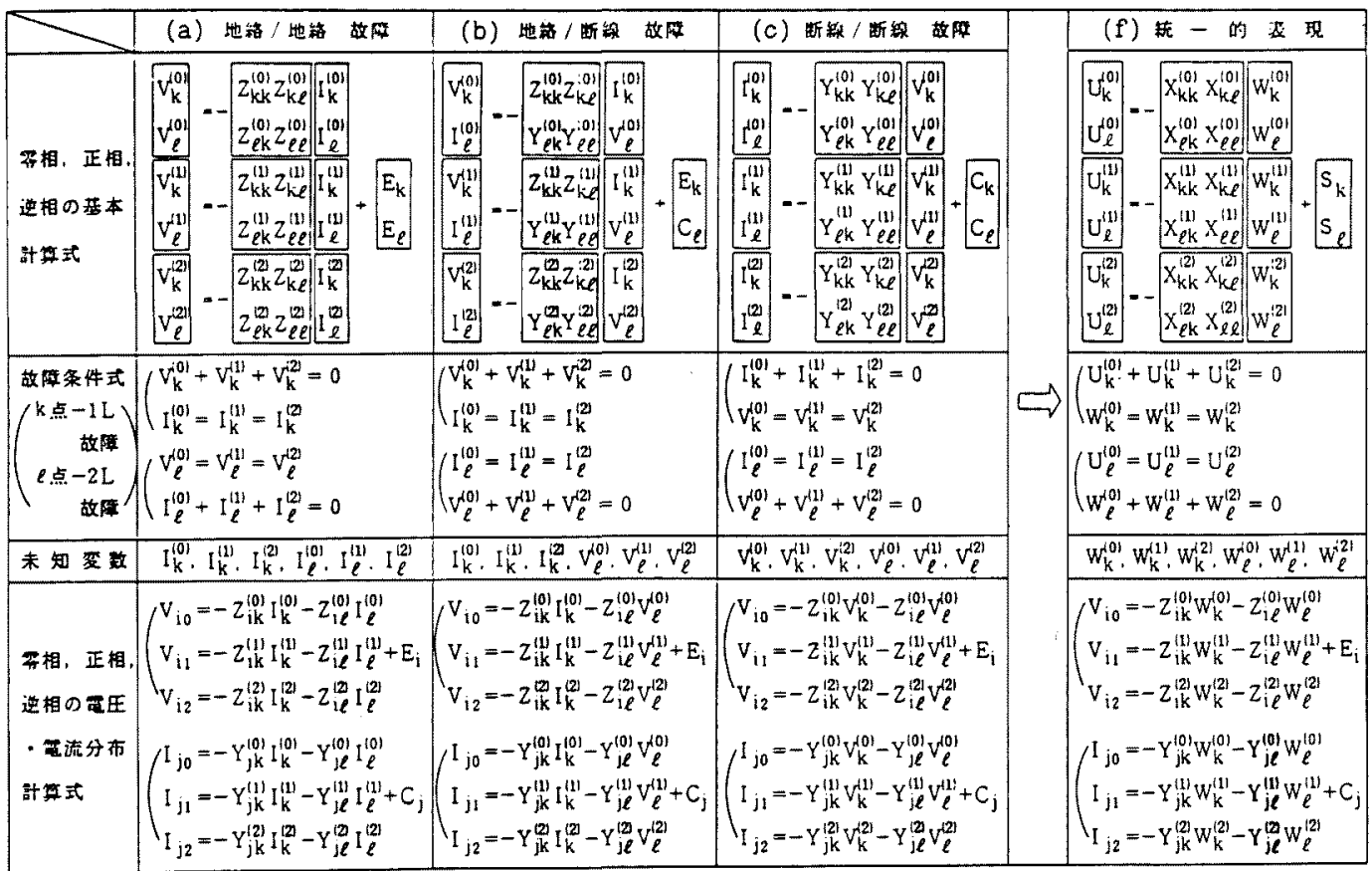

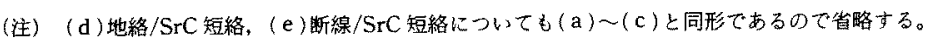

$$
\left.\begin{array}{l}
W_{k}^{(1)}=C_{1} S_{k} \\
W_{k}{ }^{(0)}=C_{0} W_{k}^{(1)} \\
W_{k}^{(2)}=C_{2} W_{k}^{(1)}
\end{array}\right\}
$$

と表すことができる。ここに，右辺の係数 $C_{n}(n=0$, 1,2）は各々の故障条件式に基づいて算出できる。結 果を整理して表 4 に示す。

安定度解析に扢ける故障計算で, 同一故障が継続中 の表 3 の $Z$ と $Y$ ベクトルおよび表 4 の係数 $C_{n}$ は変 わらない。よって実際の計算では，これらの値は外乱 条件が変化する時点でのみ 1 回だけ算出しておけばよ
い。同一故障継続中の系統計算はいったん故障なしの 状態の系統諸量 $S_{k}$ (表 $3 の E_{k}$ あるいは $C_{k}$ ) を求 め, これから算出される上記 $W_{k}$ を表 $3(\mathrm{~d})$ )電圧・ 電流方程式に代入する（故障なしの潮流分布に，故障 による潮流分布変化分を重畳する）だけでよい。

\section{$\langle 2 \cdot 3\rangle$ 多重故障計算 2 地点同時故障（多重故} 障）計算の場合も，基本的な計算手順は単純故障と変 わるところはない。ただ，故障を $k$ 点のみでなく同 時に $l$ 点（ $k=l$ でもかまわない）でも考慮する場合， 互いの故障が影響を及浮し合うため，一連の計算式が 二次元になるという点，また故障位相が非基準相のと 
表 6 多重故障計算の係数 $D$ [表 5 (f f ) に刘応]

Table 6. Coefficients used for multiple faults calculation.

\begin{tabular}{|c|c|c|c|c|c|c|c|c|c|c|c|c|}
\hline \multirow[b]{2}{*}{$D_{01}$} & \multicolumn{2}{|c|}{$1 \mathrm{~L}-1 \mathrm{~L}$} & \multicolumn{2}{|c|}{$1 \mathrm{~L}-2 \mathrm{~L}$} & \multicolumn{2}{|c|}{$1 L-3 L$} & \multicolumn{2}{|c|}{$2 L-2 L$} & \multicolumn{2}{|c|}{$2 L-3 L$} & \multicolumn{2}{|c|}{$3 L-3 L$} \\
\hline & 1 & 0 & $\begin{array}{r}1 \\
-x_{i k}^{(0)}+ \\
\Delta_{1} \\
\end{array}$ & $\begin{array}{c}0 \\
\frac{(2)}{(2)}-\mathrm{X}_{\ell E}^{(2)} \\
\Delta_{1} \\
\end{array}$ & $\begin{array}{c}1 \\
-x_{k \mathrm{k}}^{(2)} \\
X_{\ell \ell}^{(0)}\end{array}$ & 0 & $\Delta_{2}$ & $\begin{array}{l}-x_{k \ell}^{(2)} \\
-x_{\ell \ell}^{(2)}\end{array}$ & $\begin{array}{r}-\frac{\Delta_{4}}{\Delta_{5}} X_{l \ell}^{(0)} \\
\frac{\Delta_{4}}{\Delta_{5}} X_{p k}^{(0)}\end{array}$ & 0 & 0 & 0 \\
\hline$D_{21}$ & 1 & 1 & $\begin{array}{r}1 \\
x_{l k^{\prime}}^{(0)} \\
\Delta_{1} \\
\end{array}$ & $\begin{array}{c}0 \\
-\frac{-x_{\ell \ell}^{(0)}}{\Delta_{1}} \\
\end{array}$ & $\begin{array}{c}1 \\
-x_{\ell \mathrm{k}}^{(2)} \\
x_{\ell \ell}^{(2)}\end{array}$ & 0 & $\Delta_{2}{ }_{-}^{-}$ & $\begin{array}{l}-x_{\mathrm{k} \ell}^{(0)} \\
-x_{\ell L}^{(0)}\end{array}$ & $\begin{array}{r}-\frac{\Delta_{3}}{\Delta_{5}} X_{\ell \ell}^{(2)} \\
\frac{\Delta_{3}}{\Delta_{5}} X_{\ell k}^{12} \\
\end{array}$ & 0 & 0 & $\begin{array}{l}0 \\
0\end{array}$ \\
\hline$D_{00}$ & $\begin{array}{l}x_{k k}^{101} \\
x_{k k}^{(01}\end{array}$ & $x_{\ell \ell}^{(0)}$ & $x_{k k}^{101}$ & $x_{\mathrm{k} e}^{(0)}$ & $x_{k k}^{(0)}$ & $\mathrm{x}_{\mathrm{k} \ell}^{(0)}$ & 0 & 0 & 0 & 0 & r: & 0 \\
\hline$D_{11}$ & $\begin{array}{l}x_{k k}^{i n} \\
x_{\ell k}^{\prime \prime \prime}\end{array}$ & $x_{\ell \ell}^{1 !}$ & $x_{t k}^{n !}$ & $x_{k \ell}^{(1)}$ & $x_{\ell k}^{u !}$ & $\mathrm{x}_{\ell \ell}^{\text {(I) }}$ & $\begin{array}{l}x_{k k}^{11 !} \\
x_{e k}^{\prime \prime \prime}\end{array}$ & $\begin{array}{l}x_{k \ell}^{(1)} \\
x_{\ell \ell}^{(1)}\end{array}$ & $\begin{array}{l}x_{k k}^{(1)} \\
x_{\ell k}^{\prime \prime !}\end{array}$ & $\begin{array}{l}\mathrm{x}_{\mathrm{ke}}^{(1)} \\
\mathrm{x}_{\ell e}^{(1)}\end{array}$ & $\begin{array}{l}x_{k k}^{(n)} \\
x_{r k}^{m}\end{array}$ & $\begin{array}{l}\mathrm{x}_{\mathrm{k} \ell}^{1 ! \prime} \\
\mathrm{x}_{\ell \ell}^{i ! \prime}\end{array}$ \\
\hline $\mathrm{D}_{22}$ & $\begin{array}{l}x_{k \mathrm{k}}^{121} \\
x_{k \mathrm{k}}^{(21}\end{array}$ & $\begin{array}{l}x_{k e}^{121} \\
x_{i c}^{121}\end{array}$ & $\begin{array}{r}x_{l i k}^{121} \\
-x_{6 k}^{(2)}\end{array}$ & $\begin{array}{r}x_{k \ell}^{(2)} \\
-x_{\ell \ell}^{(2)}\end{array}$ & $x_{k k}^{121}$ & $x_{\mathrm{k} \ell}^{121}$ & $\begin{array}{l}-X_{\mathrm{kk}}^{12 !} \\
-X_{e \mathrm{k}}^{(2)}\end{array}$ & $\begin{array}{l}-x_{k \ell}^{[2]} \\
-x_{\ell \ell}^{(2)}\end{array}$ & $-X_{k h}^{i 2}$ & $\begin{array}{r}-x_{k \ell}^{(2)} \\
0\end{array}$ & 0 & 0 \\
\hline
\end{tabular}

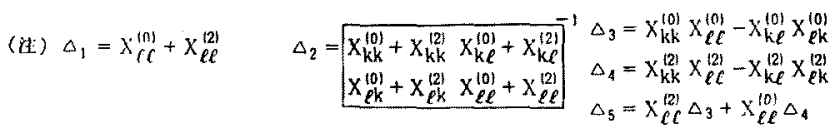

きの取扱いに注意を要する点で相違がある。

表 2 の 39 タプの多重故障に対応する基本方程式 をまとめて表 5 に示す。同表における各变数の意味 は，表 3 の単純故障の場合と同様である。なお，表 5 には故障条件式の一例として $k$ 点 $-1 L$ と $l$ 点 $-2 L$ の組合せのみを䪧述しているが，実際にはこのほかに 1L〜3Lについて 5 通りの組合せが考えられる。

表 5(a)〜(e)の方程式㹥前節の単純故障の場合と 同様に全く同形であるため，考夏られる多重故障のす ベての組合せに対応する方程式を39のタイプ別に用 意する必要はない。婊 5(f) に示す統一的表現形式に ついて 1L〜3Lの組合せからなる6タイプに関する 求解式老用意して朽きさえすればよい。

具体的に表 $5(\mathrm{f})$ 中の未知変数 $W_{k}, W_{l}$ を求めると

$$
\begin{aligned}
& {\left[D_{00}\right]\left[\begin{array}{l}
W_{k}^{(0)} \\
W_{l}^{(0)}
\end{array}\right]+\left(D_{11}\right]\left[\begin{array}{l}
W_{k}^{(1)} \\
W_{l}^{(1)}
\end{array}\right]+\left[D_{22}\right]\left[\begin{array}{l}
W_{k}^{(2)} \\
W_{l}^{(2)}
\end{array}\right]} \\
& =\left[\begin{array}{c}
S_{k} \\
S_{l}
\end{array}\right] \\
& {\left[\begin{array}{l}
W_{k}^{(2)} \\
W_{l}^{(2)}
\end{array}\right]=\left(D_{21}\right]\left[\begin{array}{l}
W_{k}^{(1)} \\
W_{l}^{(1)}
\end{array}\right]} \\
& {\left[\begin{array}{l}
W_{k}^{(0)} \\
W_{l}^{(0)}
\end{array}\right]=\left(D_{01}\right)\left[\begin{array}{l}
W_{k}^{(1)} \\
W_{l}^{(1)}
\end{array}\right]}
\end{aligned}
$$

となる。ここで,Dで表した各係数は,それぞれ $(2 \times 2)$ の大きさ正方行列である。その要素值は各々 の故障条件式に基づいて算出できる。結果を整理して 表6に示す。求めるぺきWは，(9b)式と $(9 c)$ 式学 (9a)式に代入した次式により計算できる。

$$
\begin{aligned}
& {\left[\begin{array}{l}
W_{k}^{(1)} \\
W_{l}^{(1)}
\end{array}\right]=\left[D_{11}^{\prime}\right]\left[\begin{array}{c}
S_{k} \\
S_{l}
\end{array}\right] \ldots \ldots \ldots \ldots \ldots \ldots \ldots \ldots } \\
\geq & =K, D_{11}^{\prime}=\left(D_{00} D_{01}+D_{11}+D_{22} D_{21}\right)^{-1}
\end{aligned}
$$

それぞれの $W$ の計算手順は，まず(10)式で故障なし の系統計算結果である $S_{k}$ と $S_{l}$ とから $W^{(1)}$ を求め, 次いでこの值を $(9 \mathrm{~b})$ 式，(9c) 式に逆代入して残りの $W^{(2)}, W^{(0)}$ 算出する。最終的に系統故障時に招ける 各対称分の系統諸量は,どのような故障タイプであ れ，この $W$ を表 $5(f)$ の電王・電流分布計算式に代入 することにより得ることができる。

安定度解析における故障計算では, 同一故障が継続 中梳(9)式のD変わらない。よって実際の適用に あたつては, 前節の単純故障における記述と同様の効 率的な計算手順を用いることが可能である。

〈2・4〉プログラム表 2 の故障計算機能を, 電 力中央研究所で既開発の動特性安定度解析プログラ

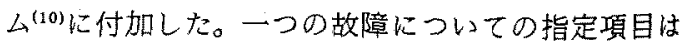


次のと㧍りである。

（1）故障種類（地絡， $\mathrm{SrC}$ 短絡，ブランチ開放）

（2）故障相 $(a, b, c の$ 任意の組合せ

（3）故障地点（ブランチの送端もしくは受端側）

（4）故障発生時間（解析開始を 0.0 秒として）

（5）地絡故障の場合, 必要に応じ故障点抵抗值 故障指定は，時系列的に任意の個数を設定できる。 故障設定による安定度解析中の各時間断面の故障様相 が単純か多重であるかは，プグラム内で自動的に判 別して必要な妈理・計算を行うこととしている。更に, 地絡故障が継続中の状態で当該ブランチの開放が指定 された場合には，自動的に地絡故障を除去するなど， 利便性を考慮した機能を備えている。

計算出力は, 不平衡の状態においてのみ, 各地点の 各相ノード電圧と各相ブランチ電流を出力する。

取扱い得る采統規模は 1,000 ノード，1,200 ブラン チである。故障計算機能の付加による安定度ブログラ 么容量の增分は, 全体の容量（約 $2 \mathrm{MB}$ )に対して $400 \mathrm{kB}$ 程度にすぎない。

計算時間は, 発電機モデルや負荷特性など他の条件 設定に大きく依存するため厳密な比較は難しいが，機 能付加による計算時間増加を概略推定するため 872 ， ード，959ブランチのモデル系統を用いて試算を行っ た。その結果, 平衡計算と比べた不平衡計算時の系統 計算 1 回あたりの計算時間は約 1.3 倍, 全体の計算を 積分刻み $(0.01$ 秒) だけ進めるのに要する時間でみ て約 1.1 倍であった（富士通 M-200 使用時）。

\section{3. 不平衡故障時の過渡安定度}

冒頭で述べたように，我が国における基幹送電線の 多くは 2 回線構成が基本となっている。しかも, 同一 鉄塔への 2 回線件架が大半であることから，2回線に またがる送電線故障に対する過渡安定度を精度良く把 握しておくことが必要である。しかしながら，これま で様々な故障の過渡安定度に及ほす影響が詳細に検 討・評価された例は見当たらない。そのため，その影 響の度合いを明らかにしておくことは，電力系統の計 画・運用の検討に有益な指針を与え得ることになる。

本章では, 再閉路方式を有する電力系統の過渡安定 度について，モデル実験との対比により前章で述べた シミュレーション解析手法の精度を検証すると共に, 種々の故障様相と過渡安定度との関係について考察す る。

〈3・1〉シミュレータによる実験電力中央研究 所の交・直流電力系統シミュレータ設備(11) 用いたモ テル実験系統を図 2(a) に示す。(b)図は対応する線

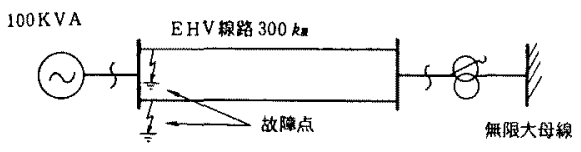

(a) 奉騒回路

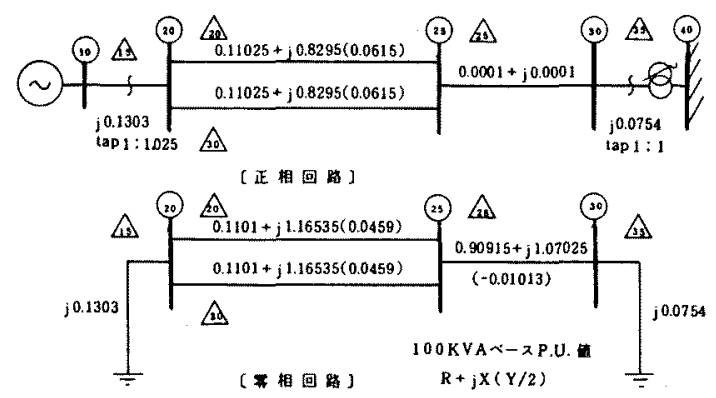

(b)シミュレーション回路

园 2 実験系統

Fig. 2. Model power system.

路定数であり, 計算機シミュレーションで回線閒零相 回路を正確に表現するため，ブランチ 20-30に仮想の ノード 25 を設けている。発電機にはPSS 付きの標準 的な AVRを設け, GOV 系は手動とした。

故障に関する実験条件は次のと㭁りである。

（1）故障様相図 308 種類の故障を対象と し，いずれも多相再閉路成功とする。故障様相選定の 理由は，我が国における多相再閉路方式採用の送電線 では，基本的に両回線にまたがる異相 2 相以上が建全 であれば再閉路を実施しているという実態による。

（2）故障条件 故障条件は，我が国の基幹系統 での現状を考慮して故障発生から遮断までの故障継続 時間を 3 サイクル, 故障遮断から再閉路までの無電圧 時間を 50 サイクルとした。また, 故障発生位置は図 2 の送電端に設定した。

実験は, 定格出力 $90 \mathrm{~kW}$ の発電機の出力を $5 \mathrm{~kW}$ 単位で変化させ, 各出力ごとに上記故障を発生させて 安定極限電力を求めた。

結果を図 3 に示す。図中の最大相差角 $\theta_{\max }$ は，同 じ安定極限電力となっている故障様相どうしの差珙を 類推するための参考として付した（一般に $\theta_{\max }$ が大 きいほど，より安定度が峳しいと推定される)。図 3 から次のことがいえる。

(i ) 単純に故障相の数が多いほど安定度が厳しいと はいえない。

（ii）過渡安定度に及ほす要因としては，地絡に伴 う発電機の加速よりも, 無電圧 (欠相) 状態が発電機 加速に与える影響のほうが大きいと推察される。 


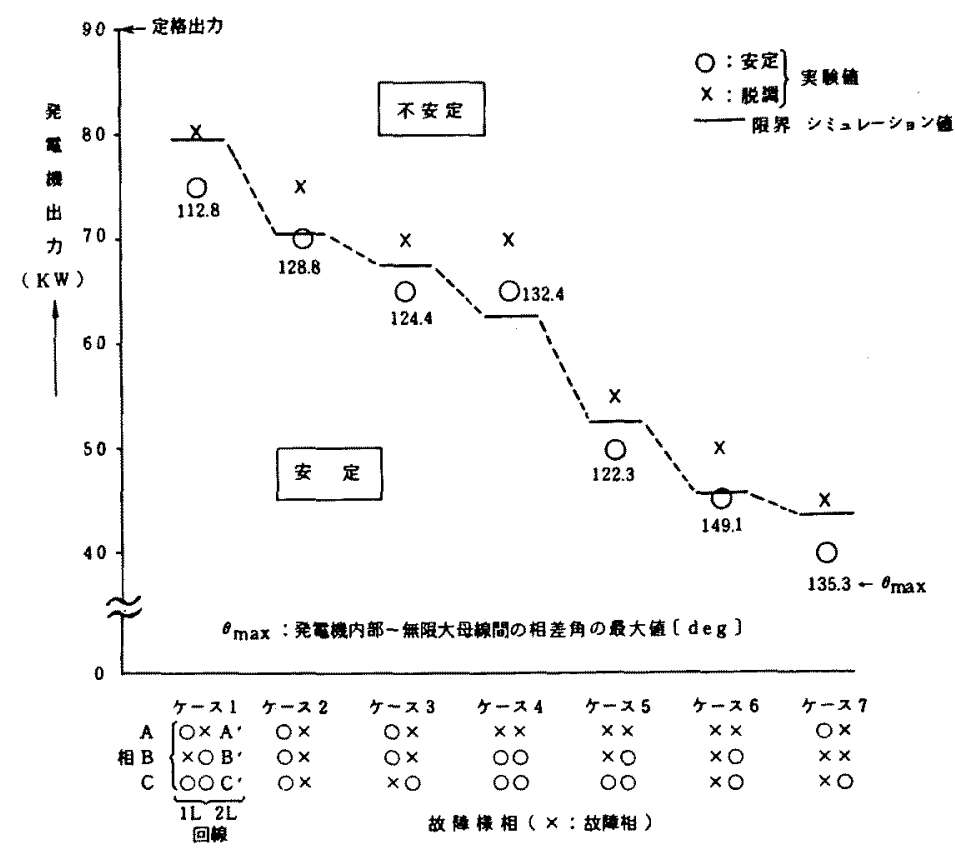

図 3 故障様相別の過渡安定度限界

Fig. 3. Transient stability limits depending on the type of fault.

こうした特徵は, 例えばケース2(片回線 $3 L G)$ とケース4（ $a a^{\prime}$ 相 $\left.2 \mathrm{LG}\right)$ の結果に見ることができ る。両者の比較では, 後者は故障相の数で 1 相だけ少 なく，しかも地絡時のショックは前者の 3 LGに対し て後者は 1 LG と格段に小さいにもかかわらず，安定 極限電力は後者が $10 \%$ 程度劣っている。

我が国に㧍ける基幹送電線の故障遮断時間は, 今後 とも安定度のいっそうの向上に向け, 短縮化の努力が はらわれよう。一方, 故障遮断から再閉路までの無電 圧時間は, 自然現象である残留アークの消隇時間との 関係から，その短縮化は容易ではない。こうした点か ら, 上記 (i)，（ii)の傾向は今後いっそう顕著になる ものと考えられる。

〈3・2〉 シミュレーション解析との対比 図 3 に 注, シミュレーション解析により安定極限電力を計算 した結果を併せて示している。シミュレーションで は, $1 \mathrm{~kW}$ 幅で発電機出力を変化させて安定極限電力 を求めた。その結果は，ケース4（ $a a^{\prime}$ 相 $\left.2 \mathrm{LG}\right)$ を除 くすべてのケースで十分に一致して（計算結果が○と ×の間に）おり，シミュレーションの精度は十分と考 えられる。

実駼結果と比較的大きな差異が見られるケース4で は,シミュレーションのほうがより厳しい結果となっ
ている。この主な理由としては,ケース4では無電圧 時の状態が他のケースと比べ最も不平衡の度合い大き く，このため実際には発電機に大きな逆相電流が流れ て2 倍周波数成分の振動トルク（逆相トルク）が生じ るが,シミュレーションではこの影響を考慮していな いためと考えられる(3)。

〈3・3〉 故障条件と過渡安定限界 今後, 必要性 が高まると考えられる不平衡故障の検討に資するため には, 図 3 で得た過渡安定限界の序列が送電距離の相 違あるいは大規模な系統の場合に変わり得るかどう か，すなわちここでの結果に十分な一般性があるかど うかを明らかにしておくことが重要である。以下で は, 図 3 の結果に基づき, 故障条件と過渡安定限界と の関係について考察する。

一般に, 安定送電限界がインピーダンス $Z$ の逆数 に比例することはよく知られている。例えばブランチ の不平衡開放の場合, $1 \mathrm{LO}$ と $2 \mathrm{LO}$ との比較では正 相回路の開放点に插入する等価インピーダンス $Z$ (以下，等価 $Z$ ) がそれぞれ

$$
\begin{aligned}
& Z_{1 \mathrm{LO}}=Z^{(0)} Z^{(2)} /\left(Z^{(0)}+Z^{(2)}\right) \\
& Z_{2 \mathrm{LO}}=Z^{(0)}+Z^{(2)}
\end{aligned}
$$

であり，両値の比較では明らかに $Z_{1 L 0}<Z_{2 L 0}$ であるこ 


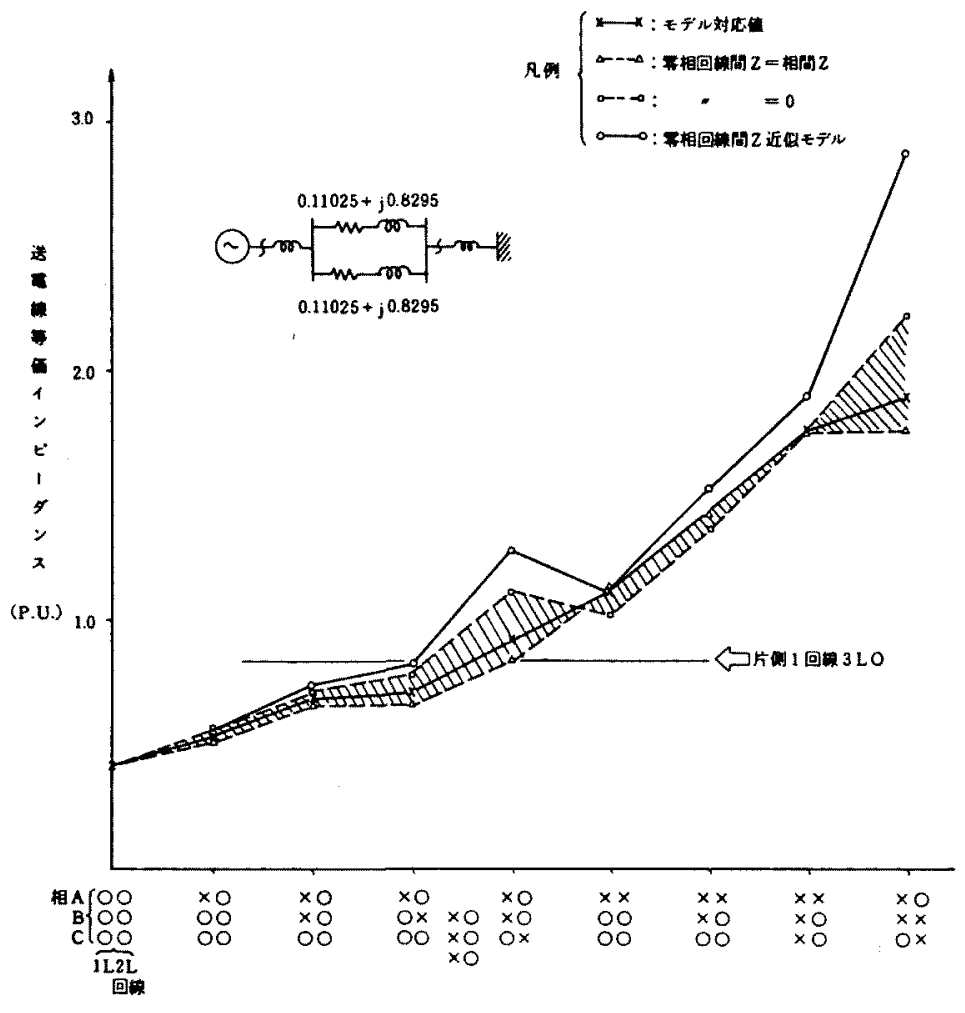

図 4 不平衡開放の等価インピーダンス

Fig. 4. Equivalent impedance corresponding to unballanced circuits open.

とから，送電限界は 2 LO の状態がより小さいことが いえる。一方，〈3・1〉節 ( 2 )項 (ii)では安定度は無電 圧状態の相違に大きく依存するという特徽を述べてお り, 従って図 3 の安定限界の傾向の検討にあたって は, $Z_{1 L O} や Z_{2\llcorner O}$ のように線路開放時の等価インピー ダンスがふさわしいと考えられる。

しかし，2 回線にまたがるブランチの無電圧（多重 断線）状態に対し，その等価 $Z$ が必要とされる場合 は多くない。しかも，Z法吊 $Z_{220}$ のように数式化が 容易でないため，めったに算出されることもない。だ が，数値的には(10)式を用いることにより，正相回路 における断線時の断線点間電位差 $V^{(1)}$ と通過電流 $I^{(1)}$ との関係式の係数として比較的容易に得ることができ る。

図4に結果を示す。×——×で示す線が本モデル系 統に対応する故障ブランチの等価 $Z$ である。この抵 抗 $Z$ は図の左から右に向けて単調に増大して（安定 度的に厳しくなって）扔り，実験やシミュレーション 結果の妥当性を裏付けたものとなっている。

この結果から，仮に系統規模が異なる場合，すなわ
ち故障ブランチ背後のインピーダンス值が異なる場合 であっても，程度の差こそあ机図 4 と類似の結果が 期待できると考えられる。ただし不平衡故障の場合, 特に零相回路に扔ける回線間インピーダンスの影響が 無視できないと考えられることから，参考までにこれ

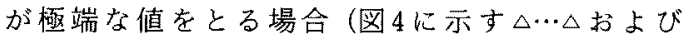
○○のケース) も計算した。故障様相の一部でイン ピーダンス值の逆転が見られるものの, 斜線で示すよ うに全体として右上がりとなる傾向は変わらない。

また, 電気事業の実務ではしばしば回線間インピー ダンスを近似表現（両回線共に常に同じ電流が流れる ものと仮定）した計算が行われることがあるので, 参 考まに零相回線間 $Z$ 近似モデルの計算結果を図 4 K 併せて示す。この場合， $Z$ はすべて大きめとなって いることから，安定度的には若干控えめな（悲観的 な）計算となるものと推察され，実務上の問題は少な いと考えら机る。

\section{4.あとがき}

対称座標法に代表される故障計算の基本論理が既に 
成熟の域にあることはよく知られている。よって，従 来不可能だった解析が本論文によって初めて可能とな つたとはいえない。

しかしながら，プログラム規模や演算時間などの計 算労力で大きな負担增をまねくことなく，1,000ノ一 ド程度の大規模系統モデルを取扱え, 安定度解析で必 要となる種々の故障様相の解析を簡便に行える実用的 なツールはこれまでに見当たらない。更に，既に現実 のものとなっている各種の故障について, それぞれの 安定度の比較を詳細に検討された例もなかった。

前者については, 従来極めて困難であった解析が本 論文での提案により容易に行えるようになったといえ よう。また後者については,一見して片回線3LG/3LO よりはより安定と考えられがちな 2 回線同相 $1 \mathrm{LG} /$ 1 LO が，実際にはより不安定であるなど, 系統運 用・計画面の検討にあたっての有益な指針を提供した。

既に提案手法は (財) 電力中央研究所が開発した動特 性安定度解析（通称 Y 法）プログラムに組込み，電 力各社の系統運用・計画関連の実用業務に広く供して いる。

故障解析手法についての今後の課題としては, 現行 プログラムでは簡略扱いとなっている回線間零相相互 インピーダンスの詳細計算機能, あるいは現行では, 一ド端に限られている故障位置についてその線路中間 点故障に対する計算機能などの拡充など, 実用性を広 け゚る課題がある。

最後に, 本研究の遂行にあたり有益な御指導を賜つ た電力中央研究所高橋一弘主席専門役, 坪井 昭情 報高度化担当に深甚なる謝意を表します。同じく電力 シテム部の安定度解析グループの面々には, 安定度解 析プログラムへの適用の具体化に際して多くの助言を いただいた。ここに感謝いたします。

(平成 3 年 7 月 22 日受付)

\section{文献}

（1）電気協同研究：「電力系統の安定度」, 電気協同研究会, 34 No. 5 (昭 54)

（2）関根：電力系統過渡解析論（昭 59）オーム社

（3）浅田, 他：「不平衡故障時の過渡安定度」, 電気学会電力技術 研資, PE-88-6 (昭 63)

（4）田中:「電力系統解析技術の基䃈と応用(III故障解析), 電気 評論, 74, No. 12,56 (平元)

（5）坪井：「電力系統の各種事故に対する故障計算と保護継電: ステムの動作解析手法」, 電中研報告, 71070 (昭 47)

(6) H. Wayne Hong: "Application of the Two-step Compen sation Method to Line-out and Line-end Fault Calcula. tion", IEEE Trans. Power Syst, PWRS-2, No. 3 (1987)

(7) 高橋: 電力シテム工学 (昭 52) コロナ社

（8）柳橋，他：「T 分岐 3 端子線路における一般化された不平 衡・多重故障計算法」, 電気学会電力技術研資, PE-87-96 (昭 62)

（9）新田目：電力系統技術計算の応用（昭 56) 電気書院

（10） 高橋, 他：「大規模電力系統の安定度総合解析システムの開 発了, 電中研総合報告, T14 (平 2)

(11) 町田, 他：「交流・直流電力系統シミュレー夕の開発」, 同上, T117 (昭 59)

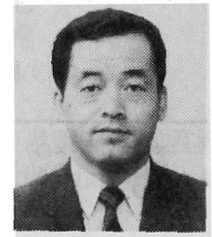

田中和幸 (正員)

昭和 26 年 12 月 30 日生。 51 年 3 月九 州大学大学院修士課程修了 (電気工学)。 同年 4 月(財)電力中央研究所入所。56 年 8 月〜 57 年 9 月アメリカ・テキサス大 学アーリントン校客員研究員。主として, 電力系統の計 画・運用・制御に関する研究に従事。平成 3 年電気学会論文 賞。平成 3 年 10 月九州工業大学客員助教授。

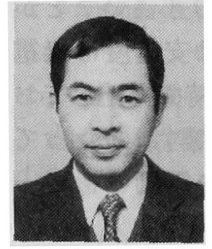

浅田実(正員)

昭和 27 年 11 月 20 日生。 46 年 3 月東 京都立小金井工業高校電気科卒業。同年 4 月 (財) 電力中央研究所入所。 51 年 3 月 東京電機大学二部電気工学科卒業。主と して, 電力系統の計画・運用・制御に関する研究に従事。 